\title{
PENGARUH TINGKAT KESEHATAN BANK TERHADAP KEBIJAKAN DIVIDEN MENGGUNAKAN METODE RGEC PADA BANK BTPN SYARIAH
}

\section{TAHUN 2015-2020}

\author{
Eka Mega Pertiwi \\ Program Studi Ekonomi Syariah, Fakultas Ekonomi dan Bisnis Islam, Universitas Islam \\ Negeri Sunan Ampel Surabaya \\ eka19mp@gmail.com
}

\begin{abstract}
Abstrak
Perbankan syariah menjadi salah satu sektor yang stabil ditengah pandemic covid-19. Sehingga banyak para investor yang melirik saham sektor perbankan syariah dengan mengharapkan memperoleh return besar dan dividen dari emiten perbankan syariah. Salah satu perusahaan perbankan syariah yang go public dan dilirik oleh para investor adalah PT. BTPN Syariah Tbk. Melalui tingkat kesehatan bank para stakeholder dapat mengambil keputusan, tak terkecuali pihak perusahaan bank untuk memutuskan kebijakan dividen. Tujuan penelitian ini adalah untuk mengetahui tingkat kesehatan bank menggunakan metode RGEC pada BTPN Syariah tahun 2015 sampai quartal 32020 dan seberapa besar pengaruh tingkat kesehatan bank menggunakan metode RGEC terhadap kebijakan dividen pada BTPN Syariah tahun 2015 sampai quartal 3 2020. Metode penelitian ini adalah penelitian kuantitatif dengan pendekatan deskriptif dan asosiatif. Hasil penelitian ini menunjukkan bahwa tingkat kesehatan BTPN Syariah tahun 2015 sampai quartal 32020 sangat sehat dan melalui predikat sangat sehat tersebut 2 rasio dari indikator penilaiannya memiliki pengaruh terhadap kebijakan dividen, serta BTPN Syariah mampu membagikan dividen ditengah pandemic covid-19 diperkuat dengan pengaruh rasio NPF sebesar 1,65 dan CAR sebesar 1,41 pada tingkat kesehatan metode RGEC terhadap rasio DPR pada kebijakan dividen.
\end{abstract}

Kata kunci: Kesehatan bank, RGEC, dividen, DPR, bank syariah

\begin{abstract}
Islamic banking has become one of the stable sectors in the midst of the COVID-19 pandemic. So that many investors are looking at shares in the Islamic banking sector with the hope of obtaining large returns and dividends from Islamic banking issuers. One of the Islamic banking companies that went public and was eyed by investors was PT. BTPN Syariah Tbk. Through the soundness of the bank, stakeholders can make decisions, including bank companies to decide dividend policy. The purpose of this study was to determine the soundness of banks using the RGEC method at BTPN Syariah in 2015 to quarter 32020 and how much influence the level of soundness of banks using the RGEC method on dividend policy at BTPN Syariah from 2015 to quarter 32020 . This research method is a quantitative study. with descriptive and associative approaches. The results of this study indicate that the health level of BTPN Syariah in 2015 until the third quarter of 2020 is very healthy and through the very healthy predicate, 2 ratios of the assessment indicators have an influence on dividend policy, and BTPN Syariah is able to distribute dividends in the midst of the covid-19 pandemic, strengthened by the influence of the NPF ratio. of 1.65 and CAR of 1.41 on the soundness of the RGEC method to the ratio of DPR on dividend policy.
\end{abstract}

Keywords: bank health, RGEC, dividends, DPR, Islamic banks 


\section{PENDAHULUAN}

Pada saat ini perekonomian global sedang dilanda krisis. Berbeda dengan tahun tahun sebelumnya yang perekonomian globalnya disebabkan oleh krisis keuangan atau krisis moneter. Namun, saat ini perekonomian global disebabkan oleh sebuah virus yang dinamakan Corona Virus Desease 2019 atau Covid-19. Virus ini ditemukan di Wuhan provinsi Hubei, China pada bulan Desember 2019. Penyebaran Covid-19 sangat cepat hingga ke seluruh penjuru dunia, termasuk Negara-negara maju seperti Amerika Serikat, Inggris, Korea Selatan, dan Jepang.

Tak terkecuali Indonesia, Covid-19 ini masuk ke Indonesia pada bulan Maret 2020. Covid-19 ini tidak hanya berdampak bagi kesehatan manusia, tetapi juga berdampak bagi perekonomian Negara. Selain menelan korban jiwa dalam jumlah banyak, Covid-19 ini juga meningkatkan angka kemiskinan. Menurut Institute for Demographic and Property Studies (Rosifah, 2021) memprediksi kemiskinan di Indonesia yang disebabkan oleh Covid-19 ini mencapai $15 \%$ yang pada mulanya hanya $9,22 \%$.

Sektor bisnis terdampak dari adanya Covid-19. Perusahaan-perusahaan yang bergerak dibidang property, pariwisata, manufaktur, otomatif, serta keuangan memiliki penuruan kinerja yang signifikan disebabkan oleh Covid-19. Selain itu, banyak UMKM yang mengalami gulung tikar disebabkan oleh Covid-19. Tak terkecuali, sektor keuangan mengalami penurunan yang sangat signifikan, namun terdapat salah satu sektor keuangan yang memiliki kinerja yang stabil disaat Covid-19 yaitu perbankan syariah.

Perbankan syariah mampu bertahan dan tumbuh dengan baik ditengah pandemic Covid-19. Perbankan syariah ini menerapkan prinsip-prinsip syariah berdaasarkan Qur'an dan hadist. Perbankan syariah tidak menerapkan sistem bunga dalam aktivitasnya karena bunga ini termasuk riba. Seperti dalam Al-Quran Surah Al-Baqarah Ayat 278 yang artinya: Hai orang-orang yang beriman, bertakwalah kepada Allah dan tinggalkan sisa riba (yang belum dipungut) jika kamu orang-orang yang beriman. (Qs. Al-Baqarah:278).

Sehingga sistem bunga ini diganti dengan sistem bagi hasil atau nisbah dan hal ini dapat meringankan sekaligus membantu para nasabah atau masyarakat. Resiko yang relative kecil pada perbankan syariah disaat Covid-19 ini dikarenakan konsep syariah yang adil, transparansi, dan kemaslahatan yang secara tidak langsung memitigasi akibat yang timbul dari pandemic Covid-19. Pertumbuhan perbankan syariah yang baik dapat dilihat dari kinerja keuangan perbankan syariah tersebut. 


\section{P ISSN 2622-7177

Kinerja keuangan bank syariah merupakan deskripsi kondisi keuangan bank syariah pada periode tertentu, baik perbulan, triwulan atau tahunan yang mencakup penghimpunan dan penyaluran dana bank syariah tersebut (Sumadi, 2020). Dalam hal ini diperlukan laporan keuangan untuk membantu menilai kinerja keuangan bank syariah tersebut. Kinerja keuangan syariah memiliki signifikan yang positif dengan tingkat kesehatannya. Sehingga, semakin baik kinerja keuangan bank syariah maka semakin baik tingkat kesehatan bank syariah, begitu juga sebaliknya, semakin buruk kinerja keuangan bank syariah maka semakin buruk tingkat kesehatan bank syariah.

Dengan kinerja keuangan bank syariah yang baik dan tingkat kesehatan bank syariah yang baik, maka banyak investor yang melirik bank tersebut. Terlebih dimasa pandemic seperti ini, investor lokal atau domestic Indonesia mengalami peningkatan dan mereka lebih tertarik di perbankan syariah. Berdasarkan data PT Kustodian Sentral Efek Indonesia (KSEI) (Company Data \& User Guide, 2020) jumlah investor lokal di Indonesia mengalami pertumbuhan di angka 51,67\% per Desember 2020 dan para investor lokal lebih minat di sektor perbankan syariah. Mereka berharap dengan memilih perbankan syariah mendapatkan dividen yang cukup banyak, mengingat dimasa pandemic Covid-19 ini perbankan syariah masih bisa bertahan.

Salah satu sektor perbankan syariah yang dilirik para investor lokal adalah PT. BTPN Syariah Tbk atau BTPS. PT. BTPN Syariah Tbk melakukan IPO pada tanggal 8 Mei 2018 dengan total saham terdaftar sebanyak 7.626.663.000 dan sudah membagikan dividen tunainya pada tahun 2019 sebesar 45,00 (IDR) per saham. Dalam Rapat Umum Pemegang Saham Tahunan (RUPST) ("PENGUMUMAN RINGKASAN RISALAH RAPAT UMUM PEMEGANG SAHAM TAHUNAN PT BANK TABUNGAN PENSIUNAN NASIONAL SYARIAH TBK," 2020) yang dilaksanakan pada hari Kamis, 16 April 2020, BTPS akan melakukan pembayaran dividen tunai sebesar Rp. 346.554.000.000,- atau sebesar Rp. 45,per lembar saham, cum 24 April 2020. 


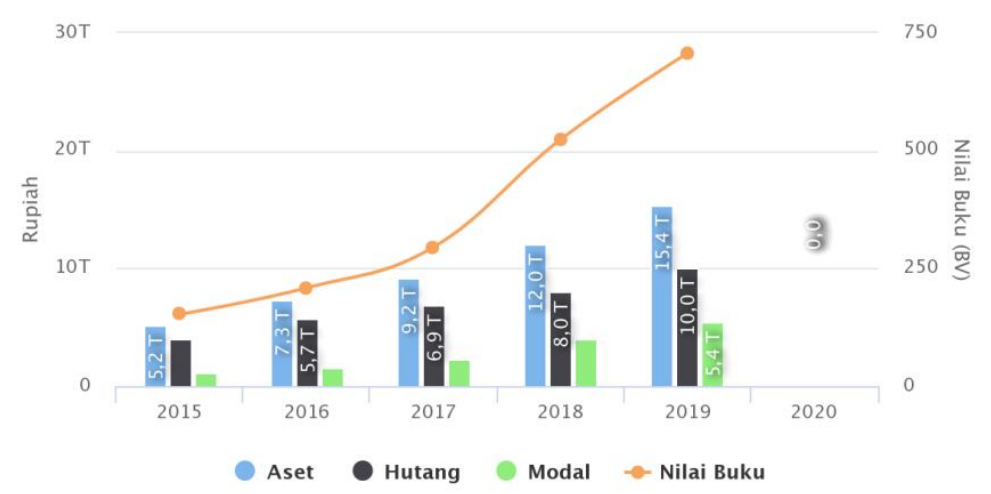

\section{Grafik 1 Akumulasi Asset, Hutang, Modal, dan Nilai Buku Bank BTPN Syariah} Periode 2015-2019

Dapat dilihat dari perbandingan asset, hutang, modal, dan nilai buku PT. BTPN Syariah Tbk pada tahun 2015-2019 masing-masing memiliki peningkatan yang signifikan. Terlebih pada nilai buku mengalami peningkatan yang tajam. Melalui nilai buku tersebut para investor dapat mengetahui PBV, dimana semakin tinggi PBV ini menandakan pasar semakin percaya akan perusahaan yang semakin membaik (Gita Maheswari \& Suryanawa, 2016). Kemudian, asset yang dimiliki BTPS juga semakin meningkat. Asset yang semakin besar tersebut akan memudahkan manajemen untuk mengendalikan dan menggunakan asset perusahaan dalam rangka meningkatkan nilai dari BTPS. Dengan ukuran perusahaan yang besar, investor berasumsi bahwa profit dari perusahaan tersebut tinggi dan dividen yang dibagikan juga besar.

Melihat kinerja keuangan PT. BTPN Syariah Tbk dengan membandingkan asset, hutang, modal, dan nilai buku dapat menjadikan salah satu alasan penilaian kondisi kesehatan bank BTPN Syariah serta dapat membantu untuk memutuskan kebijakan dividen. Tetapi, membandingkan asset, hutang, modal, dan nilai buku masih kurang untuk mengetahui kondisi kesehatan bank dan belum bisa membantu memutuskan kebijakan dividen. Diperlukan analisis kesehatan bank yang lebih dalam lagi. Sehingga kita dapat mengetahui kondisi kesehatan bank tersebut dan perusahaan dapat memutuskan kebijakan dividen yang akan diambil.

Analisis kesehatan bank dapat dilakukan dengan dua metode yaitu CAMELS dengan komponen Capital, Assets, Management, Earning, Liquidity, and Sensitivity to Market Risk atau RGEC dengan komponen Risk Profile, Good Corporate Governance, Earning, and Capital (Prastyananta dkk., 2016). Namun, Bank Indonesia mengeluarkan Peraturan Bank Indonesia (PBI) No. 13/1/PBI./2011 diissued Januari 2011 dan efektif pada Januari 2012 


\section{P ISSN 2622-7177 \\ [ACCOUNTING GLOBAL JOURNAL] E ISSN 2623-1778}

meresmikan RGEC merupakan metode terbaru dan lebih efektif untuk menganalisis kesehatan bank.

Dengan penilaian analisis kesehatan bank yang baik, maka banyak masyarakat yang percaya terhadap kinerja bank tersebut. Selain itu, para investor menilai jika analisis kesehatan bank tersebut baik, maka bank tersebut memiliki profit yang besar dan mampu membagikan dividen. Dan, melalui analisis kesehatan bank dapat membantu perusahaan untuk mengambil keputusan, termasuk keputusan dalam mengambil kebijakan dividen. Seperti dalam penelitian Martha dan Slamet (Agni \& Sugiri, 2015) menghasilkan analisis kesehatan bank pada rasio NPL, PDN, dan ROA mempunyai pengaruh yang signifikan terhadap kebijakan dividen.

Berdasarkan hal tersebut penulis melakukan penelitian dengan judul "Pengaruh Tingkat Kesehatan Bank Terhadap Kebijakan Dividen Menggunakan Metode RGEC Pada Bank BTPN Syariah Tahun 2014-2020” dengan tujuan untuk mengetahui komponen analisis kesehatan bank metode RGEC yang menjadi faktor dalam pengambilan keputusan kebijakan dividen mengingat peran PT. BTPN Syariah Tbk ini sangat membantu Negara untuk memulihkan perekonomian saat Covid-19 dan membantu masyarakat dalam pembiayaan ditengah Covid-19 serta membantu meningkatkan inklusi pasar modal Indonesia saat pandemic Covid-19.

\section{TINJAUAN PUSTAKA}

\subsection{Kesehatan Bank}

Kesehatan bank dapat diartikan sebagai tolak ukur suatu bank dalam mengoperasikan kegiatan perbankan secara normal sehingga dapat memenuhi kewajibannya atau melaksanakan fungsinya dengan baik dan sesuai dengan peraturan yang berlaku (Santoso \& Nuritomo, 2014). Berdasarkan peraturan BI No. 13/I/PBI/2011 tanggal 5 Januari tentang penilaian tingkat kesehatan bank umum, tingkat kesehatan bank merupakan hasil penilaian kondisi bank yang dilakukan terhadap resiko dan kinerja bank. Dalam pengertian lainnya, tingkat kesehatan bank adalah gambaran dari sebuah bank yang dapat menjalankan fungsinya dengan baik. Secara sederhana, bank yang sehat adalah bank yang dapat menjaga dan memelihaa kepercayaan masyarakat. Bank yang sehat dapat menjalankan fungsi intermediasi dan membantu kelancaran pembayaran. Selain itu, bank yang sehat dapat membantu pemerintah dalam melaksanakan berbagai kebijakannya terutama kebijakan moneter. Tingkat kesehatan bank dibagi dalam lima kategori sebagai berikut (Ardyanfitri dkk., 2019). 


\begin{tabular}{|c|c|c|}
\hline No. & Kategori & Peringkat Komposit \\
\hline 1. & Sangat Sehat & PK-1 \\
\hline 2. & Sehat & PK-2 \\
\hline 3. & Cukup Sehat & PK-3 \\
\hline 4. & Kurang Sehat & PK-4 \\
\hline 5. & Tidak Sehat & PK-5 \\
\hline
\end{tabular}

Tabel 1 Peringkat Komposit Tingkat Kesehatan Bank

\subsection{Metode RGEC}

Peraturan Indonesia Nomor 13/1/PBI/2011 tanggal 5 Januari 2011 tentang penilaian tingkat kesehatan bank umum yaitu risk profile, good corporate governance, earning and capital atau disingkat RGEC. Dengan adanya metode RGEC ini bank dapat mengidentifikasi permasalahan lebih awal, kemudian menindak lanjuti perbaikan dengan sesuai dan lebih cepat, dan mampu menerapkan good corporate governance yang baik, seta mampu meminimalisir manajemen risiko yang baik (Fortrania \& Oktaviana, 2015). Sehingga, bank mampu bertumbuh di tengah krisis yang melanda. Analisis kesehatan bank menggunakan metode RGEC memiliki empat komponen yaitu:

\section{Risk Profile}

Penilaian risk profile merupakan penilaian terhadap risiko inheren dan kualitas penerapan manajemen risiko dalam aktivitas operasional bank. Risk profile dinilai berdasarkan risiko kredit, risiko pasar, risiko likuiditas, risiko operasional, risiko hukum, risiko stratejik, risiko kepatuhan, risiko reputasi, risiko imbal hasil, dan risiko investasi. Penilaian atas risiko inheren dilakukan dengan memperhatikan indikator yang bersifat kuantitatif maupun kualitatif. Penetapan tingkat risiko inheren atas masingmasing jenis risiko dan rasio yang digunakan adalah NPF (Non Performing Finance) dan FDR (Finance to Deposit Ratio).

2. Good Corporate Governance

Dalam PBI No. 13/1/PBI/2011 penilaian terhadap faktor GCG adalah penilaian terhadap manajemen bank atas prinsip-prinsip GCG. Adapun prinsip-prinsip GCG tersebut diantaranya adalah keterbukaan, akuntabilitas, tanggung jawab, independensi, serta kewajaran. GCG dapat diukur dengan menggunakan rasio PDN.

3. Earning

Dalam PBI No. 13/1/PBI/2011 penilaian faktor earning meliputi evaluasi terhadap kinerja rentabilitas, sumber-sumber rentabilitas, sustainability rentabilitas, manajemen 
rentabilitas, dan pelaksanaan fungsi sosial. Earning dapat diukur dengan menggunakan rasio ROA, ROE, NI, dan BOPO.

4. Capital

Dalam PBI No. 13/1/PBI/2011 penilaian faktor capital atau permodalan meliputi evaluasi terhadap kecukupan modal dan kecukupan pengelolaan permodalan. Dalam melakukan perhitungan permodala, bank mengacu pada ketentuan yang berlaku mengenai kewajiban penyediaan modal minimum bagi bank. Selain itu, dalam melakukan penilaian kecukupan modal, bank juga harus mengaitkan kecukupan modal dengan profil risiko. Semakin tinggi risiko, semakin besar modal yang harus disediakan untuk mengantisipasi risiko tersebut. Capital atau perodalan dapat diukur dengan menggunakan rasio CAR.

\subsection{Kebijakan Dividen}

Kebijakan dividen berhubungan dengan penentuan besarnya dividend payout ratio yaitu besarnya persentase laba bersih setelah pajak yang dibagikan sebagai dividen kepada pemegang saham (Apriliani \& Natalylova, 2017). Dividen adalah pembagian kepada para pemegang saham dari suatu perusahaan secara proporsioanl sesuai dengan jumlah lembar saham yang dipegang oleh masing-masing pemilik. Besar kecilnya dividen yang dibayarkan kepada pemegang saham tergantung dari kebijakan dividen masing-masing perusahaan dan ditentukan dalam Rapat Umum Pemegang Saham (RUPS). Keputusan dividen merupakan bagian dari keputusan pembelanjaan perusahaan, khususnya berkaitan dengan pembelanjaan internal perusahaan. Tidak seing muncul konflik kepentingan antara pihak manajemen perusahaan dengan pihak pemegang saat memutuskan kebijakan dividen. Dalam perspektif manajemen perusahaan, kebijakan dividen sangat sulit karena pembagian dividen akan memenui harapan investor untuk mendapatkan return sebagai keuntungan dari investasi yang dilakukannya. Namun, manajemen perusahaan juga harus memikirkan operasional perusahaan. Sehingga, manajemen perusahaan harus menentukan suatu kebijakan dividen yang optimal dan adil antara pemegang saham dan pertumbuhan perusahaan.

\section{METODE PENELITIAN}

\subsection{Jenis Penelitian}

Penelitian ini termasuk jenis penelitian kuantitatif. Jenis penelitian kuantitatif menggunakan data yang berupa angka atau bilangan perhitungan untuk menarik sebuah kesimpulan (Sugiyono, 2018). Adapun metode yang digunakan adalah metode pendekatan deskriptif dan asosiatif. Penelitian deskriptif untuk menjelaskan keadaan atau nilai dari satu 
atau lebih variabel secara mandiri. Sedangkan, penelitian asosiatif untuk menjelaskan dan menguji hubungan dua variabel atau lebih. Objek penelitian yang diteliti oleh penulis adalah PT. BTPN Syariah Tbk dengan menganalisis tingkat kesehatan bank menggunakan metode RGEC periode 2015 sampai quartal 3 2020, kemudian menganalisis pengaruh tingkat kesehatan bank terhadap kebijakan dividen menggunakan analisis regresi berganda pada uji simultan dan uji parsial. Dalam penelitian ini jenis data yang digunakan adalah data sekunder kuantitatif perusahaan dalam bentuk laporan keuangan tahunan yang diperoleh dengan cara mengunduh laporan keuangan tahunan periode 2015-2019 dan laporan triwulan 3 periode 2020 pada laman website Bank BTPN Syariah.

\subsection{Teknik Pengumpulan Data}

\subsection{Operasionalisasi Variabel Penelitian}

Operasionalisasi variabel menggambarkan konsep variabel secara umum serta keterangan-keterangan lain tentang indikator, ukuran, dan skala pengukuran variabel. Variabel dalam penelitian ini yaitu variabel independen (X) yang dimaksudkan adalah tingkat kesehatan bank menggunakan metode RGEC dan variabel dependen (Y) yang dimaksudkan adalah kebijakan dividen mengunakan rasio DPR.

\subsubsection{Tingkat Kesehatan Bank Metode RGEC (X)}

Metode RGEC menurut surat edaran Bank Indonesia No. 13/24/DPNP meliputi faktorfaktor sebagai berikut:

1. Risk Profile

Indikator yang digunakan penilaian risk profile sebagai berikut:

a. Risiko Kredit

Indikator penilaian yang digunakan pada risiko kredit adalah rasio NPF dengan perhitungan sebagai berikut.

$$
N P F=\frac{\text { Pembiayaan Bermasalah }}{\text { Total Kredit }} \times 100 \%
$$

Adapun klasifikasi peringkat komposit NPF:

\begin{tabular}{|c|c|c|}
\hline Peringkat & Nilai Komposit & Predikat \\
\hline 1 & $\mathrm{NPF} \leq 2 \%$ & Sangat Sehat \\
\hline 2 & $2 \% \leq \mathrm{NPF}<5 \%$ & Sehat \\
\hline 3 & $5 \% \leq \mathrm{NPF}<8 \%$ & Cukup Sehat \\
\hline 4 & $8 \% \leq \mathrm{NPF}<12 \%$ & Kurang Sehat \\
\hline 5 & $\mathrm{NPF} \geq 12 \%$ & Tidak Sehat \\
\hline
\end{tabular}

Tabel 2 Klasifikasi Peringkat Komposit NPF 
b. Risiko Likuiditas

Indikator penilaian yang digunakan pada risiko likuiditas adalah rasio FDR dengan perhitungan sebagai berikut.

$$
F D R=\frac{\text { Jumlah Kredit yang Diberikan }}{\text { Total Dana Pihak Ketiga }} \times 100 \%
$$

Adapun klasifikasi peringkat komposit FDR:

\begin{tabular}{|c|c|c|}
\hline Peringkat & Nilai Komposit & Predikat \\
\hline 1 & Rasio Lebih dari $50 \%$ sampai dengan $\leq 75 \%$ & Sangat Sehat \\
\hline 2 & Rasio Lebih dari 75\% sampai dengan $\leq 85 \%$ & Sehat \\
\hline 3 & Rasio $>85 \%$ sampai dengan $\leq 100 \%$ & Cukup Sehat \\
\hline 4 & Rasio Lebih dari $100 \%$ sampai dengan $\leq$ & Kurang Sehat \\
& Lebih dari $120 \%$ & \\
\hline 5 & Tidak Sehat \\
\hline
\end{tabular}

Tabel 3 Klasifikasi Peringkat Komposit FDR

2. GCG

Indikator penilaian yang digunakan pada GCG adalah rasio PDN dengan perhitungan sebagai berikut.

$$
P D N=\frac{\text { Selisih Aset dan Liabilitas Valas }}{\text { Total Modal }} \times 100 \%
$$

Adapun klasifikasi peringkat komposit PDN:

\begin{tabular}{|c|c|c|}
\hline Peringkat & Nilai Komposit & Predikat \\
\hline 1 & Tidak ada pelanggaran rasio PDN & Sangat Sehat \\
\hline 2 & $\begin{array}{c}\text { Tidak ada pelanggaran rasio PDN namun } \\
\text { pernah melakukan pelanggaran dan telah } \\
\text { diselesaikan }\end{array}$ & Sehat \\
\hline 3 & $\begin{array}{c}\text { Pelanggaran rasio PDN }>0 \% \text { sampai dengan } \\
<10 \%\end{array}$ & Cukup Sehat \\
\hline 4 & $\begin{array}{c}\text { Pelanggaran rasio PDN }>10 \% \text { sampai dengan } \\
<25 \%\end{array}$ & Kurang Sehat \\
\hline 5 & Pelanggaran PDN lebih dari $25 \%$ & Tidak Sehat \\
\hline
\end{tabular}

Tabel 4 Klasifikasi Peringkat Komposit PDN

\section{Earnings}

Indikator yang digunakan pada earnings sebagai berikut:

a. ROA (Return Of Assets)

$$
R O A=\frac{\text { Laba Sebelum Pajak }}{\text { Rata }- \text { rata Total Asset }} \times 100 \%
$$

Adapun klasifikasi peringkat komposit ROA:

\begin{tabular}{|l|l|l|}
\hline Peringkat & Nilai Komposit & Predikat \\
\hline
\end{tabular}




\begin{tabular}{|c|c|c|}
\hline 1 & ROA $\geq 2 \%$ & Sangat Sehat \\
\hline 2 & $1,26 \% \leq \mathrm{ROA}<5 \%$ & Sehat \\
\hline 3 & $0,51 \% \leq \mathrm{ROA}<1,25 \%$ & Cukup Sehat \\
\hline 4 & $0 \% \leq \mathrm{ROA}<0,5 \%$ & Kurang Sehat \\
\hline 5 & $\mathrm{ROA}<0 \%$ & Tidak Sehat \\
\hline
\end{tabular}

Tabel 5 Klasifikasi Peringkat Komposit ROA

b. ROE (Return Of Equaity)

$$
R O E=\frac{\text { Laba Setelah Pajak }}{\text { Rata }- \text { Rata Total Modal }} \times 100 \%
$$

Adapun klasifikasi peringkat komposit ROE:

\begin{tabular}{|c|c|c|}
\hline Peringkat & Nilai Komposit & Predikat \\
\hline 1 & ROE $\geq 20 \%$ & Sangat Sehat \\
\hline 2 & $12,51 \% \leq \mathrm{ROE}<20 \%$ & Sehat \\
\hline 3 & $5,01 \% \leq \mathrm{ROE}<12,5 \%$ & Cukup Sehat \\
\hline 4 & $0 \% \leq \mathrm{ROE}<5 \%$ & Kurang Sehat \\
\hline 5 & $\mathrm{ROE}<0 \%$ & Tidak Sehat \\
\hline
\end{tabular}

Tabel 6 Klasifikasi Peringkat Komposit ROE

c. NI

$$
N I=\frac{\text { Pendapatan Imbalan }}{\text { Rata }- \text { Rata Asset Produktif }} \times 100 \%
$$

Adapun klasifikasi peringkat komposit NI:

\begin{tabular}{|c|c|c|}
\hline Peringkat & Nilai Komposit & Predikat \\
\hline 1 & $\mathrm{NI} \geq 6,5 \%$ & Sangat Sehat \\
\hline 2 & $2,01 \% \leq \mathrm{NI}<6,5 \%$ & Sehat \\
\hline 3 & $1,5 \% \leq \mathrm{NI}<2 \%$ & Cukup Sehat \\
\hline 4 & $0 \% \leq \mathrm{NI}<1,49 \%$ & Kurang Sehat \\
\hline 5 & $\mathrm{NI}<0 \%$ & Tidak Sehat \\
\hline
\end{tabular}

\section{Tabel 7 Klasifikasi Peringkat Komposit NI}

d. BOPO

$$
B O P O=\frac{\text { Biaya Operasional }}{\text { Pendapatan Operasional }} \times 100 \%
$$

Adapun klasifikasi peringkat komposit BOPO:

\begin{tabular}{|c|c|c|}
\hline Peringkat & Nilai Komposit & Predikat \\
\hline 1 & Kurang dari $88 \%$ & Sangat Sehat \\
\hline 2 & $89 \%$ sampai dengan $93 \%$ & Sehat \\
\hline 3 & $94 \%$ sampai dengan $96 \%$ & Cukup Sehat \\
\hline 4 & $97 \%$ sampai dengan $100 \%$ & Kurang Sehat \\
\hline 5 & Lebih dari $100 \%$ & Tidak Sehat \\
\hline
\end{tabular}




\section{[ACCOUNTING GLOBAL JOURNAL] E ISSN 2623-1778}

\section{Tabel 8 Klasifikasi Peringkat Komposit BOPO}

4. Capital

Indikator penilaian yang digunakan pada Capital adalah rasio CAR dengan perhitungan sebagai berikut.

$$
C A R=\frac{\text { Modal }}{\text { ATMR }} x 100 \%
$$

Adapun klasifikasi peringkat komposit CAR:

\begin{tabular}{|c|c|c|}
\hline Peringkat & Nilai Komposit & Predikat \\
\hline 1 & $\mathrm{CAR} \geq 12 \%$ & Sangat Sehat \\
\hline 2 & $9 \% \leq \mathrm{CAR}<12 \%$ & Sehat \\
\hline 3 & $8 \% \leq \mathrm{CAR}<9 \%$ & Cukup Sehat \\
\hline 4 & $6 \% \leq \mathrm{CAR}<8 \%$ & Kurang Sehat \\
\hline 5 & $\mathrm{CAR} \leq 6 \%$ & Tidak Sehat \\
\hline
\end{tabular}

Tabel 9 Klasifikasi Peringkat Komposit CAR

\subsubsection{Kebijakan Dividen (Y)}

Rasio yang digunakan untuk menentukan kebijakan dividen adalah DPR atau Dividend Payout Ratio. Adapun perhitungan dari DPR seperti berikut.

$$
D P R=\frac{\text { Total dividen }}{\text { Laba bersih }} \times 100 \%
$$

\subsection{Teknik Analisis Data}

\subsubsection{Analisis Deskriptif}

Analisis deskriptif digunakan untuk menganalisa dan menjelaskan perkembangan tingkat kesehatan bank menggunakan metode RGEC dengan rasio NPF, FDR, PDN, ROA, ROE, NI, BOPO, dan CAR, serta menjelaskan kebijakan dividen Bank BTPN Syariah.

\begin{tabular}{|c|c|c|c|c|}
\hline \multicolumn{2}{|c|}{ Penilaian } & \multicolumn{3}{c|}{ Pengukuran } \\
\hline Rangking & Poin & Bobot $(\%)$ & Kategori & Predikat \\
\hline 1 & 5 & PK-5 & $<40$ & Tidak Sehat \\
\hline 2 & 4 & PK-4 & $41-60$ & Kurang Sehat \\
\hline 3 & 3 & PK-3 & $61-70$ & Cukup Sehat \\
\hline 4 & 2 & PK-2 & $71-85$ & Sehat \\
\hline 5 & 1 & PK-1 & $86-100$ & Sangat Sehat \\
\hline
\end{tabular}

Tabel 10 Penilaian dan Pengukuran Peringkat Komposit Tingkat Kesehatan Bank

\section{Syariah}

\begin{tabular}{|c|c|c|c|c|c|c|c|c|}
\hline \multirow{2}{*}{ Tahun } & \multicolumn{7}{|c|}{ Indikator Rasio } \\
\cline { 2 - 9 } & NPF & FDR & PDN & ROA & ROE & NI & BOPO & CAR \\
\hline 2015 & $0,17 \%$ & $96,54 \%$ & $0,00 \%$ & $5,24 \%$ & $17,89 \%$ & $34,31 \%$ & $85,32 \%$ & $19,92 \%$ \\
\hline Rangking & 1 & 3 & 1 & 1 & 2 & 1 & 1 & 1 \\
\hline
\end{tabular}




\section{[ACCOUNTING GLOBAL JOURNAL] E ISSN 2623-1778}

\begin{tabular}{|c|c|c|c|c|c|c|c|c|}
\hline Poin & 5 & 3 & 5 & 5 & 4 & 5 & 5 & 5 \\
\hline Predikat & $\begin{array}{l}\text { Sangat } \\
\text { Sehat }\end{array}$ & $\begin{array}{l}\text { Cukup } \\
\text { Sehat }\end{array}$ & $\begin{array}{l}\text { Sangat } \\
\text { Sehat }\end{array}$ & $\begin{array}{l}\text { Sangat } \\
\text { Sehat }\end{array}$ & Sehat & $\begin{array}{l}\text { Sangat } \\
\text { Sehat }\end{array}$ & $\begin{array}{l}\text { Sangat } \\
\text { Sehat }\end{array}$ & $\begin{array}{c}\text { Sangat } \\
\text { Sehat }\end{array}$ \\
\hline 2016 & $0,20 \%$ & $92,75 \%$ & $0,00 \%$ & $8,98 \%$ & $31,71 \%$ & $31,71 \%$ & $75,14 \%$ & $23,80 \%$ \\
\hline Rangking & 1 & 3 & 1 & 1 & 1 & 1 & 1 & 1 \\
\hline Poin & 5 & 3 & 5 & 5 & 5 & 5 & 5 & 5 \\
\hline Predikat & $\begin{array}{l}\text { Sangat } \\
\text { Sehat }\end{array}$ & $\begin{array}{l}\text { Cukup } \\
\text { Sehat }\end{array}$ & $\begin{array}{l}\text { Sangat } \\
\text { Sehat }\end{array}$ & $\begin{array}{l}\text { Sangat } \\
\text { Sehat }\end{array}$ & $\begin{array}{l}\text { Sangat } \\
\text { Sehat }\end{array}$ & $\begin{array}{l}\text { Sangat } \\
\text { Sehat }\end{array}$ & $\begin{array}{l}\text { Sangat } \\
\text { Sehat }\end{array}$ & $\begin{array}{c}\text { Sangat } \\
\text { Sehat }\end{array}$ \\
\hline 2017 & $0,05 \%$ & $92,47 \%$ & $0,00 \%$ & $11,19 \%$ & $36,50 \%$ & $35,96 \%$ & $68,81 \%$ & $28,91 \%$ \\
\hline Rangking & 1 & 3 & 1 & 1 & 1 & 1 & 1 & 1 \\
\hline Poin & 5 & 3 & 5 & 5 & 5 & 5 & 5 & 5 \\
\hline Predikat & $\begin{array}{c}\text { Sangat } \\
\text { Sehat }\end{array}$ & $\begin{array}{l}\text { Cukup } \\
\text { Sehat }\end{array}$ & $\begin{array}{l}\text { Sangat } \\
\text { Sehat }\end{array}$ & $\begin{array}{l}\text { Sangat } \\
\text { Sehat }\end{array}$ & $\begin{array}{l}\text { Sangat } \\
\text { Sehat }\end{array}$ & $\begin{array}{l}\text { Sangat } \\
\text { Sehat }\end{array}$ & $\begin{array}{l}\text { Sangat } \\
\text { Sehat }\end{array}$ & $\begin{array}{c}\text { Sangat } \\
\text { Sehat }\end{array}$ \\
\hline 2018 & $0,02 \%$ & $95,60 \%$ & $0,00 \%$ & $12,37 \%$ & $30,82 \%$ & $32,42 \%$ & $62,36 \%$ & $40,92 \%$ \\
\hline Rangking & 1 & 3 & 1 & 1 & 1 & 1 & 1 & 1 \\
\hline Poin & 5 & 3 & 5 & 5 & 5 & 5 & 5 & 5 \\
\hline Predikat & $\begin{array}{l}\text { Sangat } \\
\text { Sehat }\end{array}$ & $\begin{array}{l}\text { Cukup } \\
\text { Sehat }\end{array}$ & $\begin{array}{l}\text { Sangat } \\
\text { Sehat }\end{array}$ & $\begin{array}{l}\text { Sangat } \\
\text { Sehat }\end{array}$ & $\begin{array}{l}\text { Sangat } \\
\text { Sehat }\end{array}$ & $\begin{array}{l}\text { Sangat } \\
\text { Sehat }\end{array}$ & $\begin{array}{c}\text { Sangat } \\
\text { Sehat }\end{array}$ & $\begin{array}{c}\text { Sangat } \\
\text { Sehat }\end{array}$ \\
\hline 2019 & $0,26 \%$ & $95,27 \%$ & $0,00 \%$ & $13,58 \%$ & $31,20 \%$ & $31,33 \%$ & $58,07 \%$ & $44,70 \%$ \\
\hline Rangking & 1 & 3 & 1 & 1 & 1 & 1 & 1 & 1 \\
\hline Poin & 5 & 3 & 5 & 5 & 5 & 5 & 5 & 5 \\
\hline Predikat & $\begin{array}{l}\text { Sangat } \\
\text { Sehat }\end{array}$ & $\begin{array}{l}\text { Cukup } \\
\text { Sehat }\end{array}$ & $\begin{array}{l}\text { Sangat } \\
\text { Sehat }\end{array}$ & $\begin{array}{l}\text { Sangat } \\
\text { Sehat }\end{array}$ & $\begin{array}{l}\text { Sangat } \\
\text { Sehat }\end{array}$ & $\begin{array}{l}\text { Sangat } \\
\text { Sehat }\end{array}$ & $\begin{array}{l}\text { Sangat } \\
\text { Sehat }\end{array}$ & $\begin{array}{c}\text { Sangat } \\
\text { Sehat }\end{array}$ \\
\hline 2020 & $0,00 \%$ & $98,48 \%$ & $0,00 \%$ & $5,80 \%$ & $12,79 \%$ & $24,13 \%$ & $77,20 \%$ & $43,10 \%$ \\
\hline Rangking & 1 & 3 & 1 & 1 & 2 & 1 & 1 & 1 \\
\hline Poin & 5 & 3 & 5 & 5 & 4 & 5 & 5 & 5 \\
\hline Predikat & $\begin{array}{c}\text { Sangat } \\
\text { Sehat }\end{array}$ & $\begin{array}{c}\text { Cukup } \\
\text { Sehat }\end{array}$ & $\begin{array}{l}\text { Sangat } \\
\text { Sehat }\end{array}$ & $\begin{array}{l}\text { Sangat } \\
\text { Sehat }\end{array}$ & Sehat & $\begin{array}{l}\text { Sangat } \\
\text { Sehat }\end{array}$ & $\begin{array}{l}\text { Sangat } \\
\text { Sehat }\end{array}$ & $\begin{array}{c}\text { Sangat } \\
\text { Sehat }\end{array}$ \\
\hline
\end{tabular}

Tabel 11 Hasil Analisis Kesehatan Bank BTPN Syariah Periode 2015 sampai Quartal

\section{0}

\subsubsection{Analisis Asosiatif}

Analisis asosiatif digunakan untuk mengetahui rasio pada tingkat kesehatan metode RGEC yang memiliki pengaruh terhadap kebijakan dividen pada Bank BTPN Syariah. Dalam hal ini analisis asosiatif menggunakan Uji $\mathrm{T}$ atau uji regresi secara parsial dan Uji $\mathrm{F}$ atau uji regresi secara simultan. Adapun pengolahannya menggunakan E-Views.

Dependent Variable: DPR

Method: Least Squares

Date: 01/12/21 Time: 08:47

Sample: 20152020

Included observations: 6

\begin{tabular}{ccccc}
\hline \hline Variable & Coefficient & Std. Error & t-Statistic & Prob. \\
\hline \hline $\mathrm{C}$ & -1.060342 & 1.951549 & -0.543333 & 0.6247
\end{tabular}


[ACCOUNTING GLOBAL JOURNAL]

\begin{tabular}{lrlrr}
\multicolumn{1}{c}{ NPF } & 71.39598 & 43.29843 & 1.648928 & 0.1977 \\
\multicolumn{1}{c}{ FDR } & 1.072084 & \multicolumn{1}{c}{2.033570} & 0.527193 & 0.6346 \\
\hline \hline R-squared & 0.475603 & Mean dependent var & 0.043417 \\
Adjusted R-squared & 0.126005 & S.D. dependent var & 0.106349 \\
S.E. of regression & 0.099423 & Akaike info criterion & -1.472015 \\
Sum squared resid & 0.029655 & Schwarz criterion & -1.576135 \\
Log likelihood & 7.416046 & Hannan-Quinn criter. & -1.888817 \\
F-statistic & 1.360429 & Durbin-Watson stat & 1.118593 \\
Prob(F-statistic) & 0.379743 & & \\
\hline \hline
\end{tabular}

Tabel 12 Indikator Rasio NPF dan FDR Terhadap DPR

Dependent Variable: DPR

Method: Least Squares

Date: 01/12/21 Time: 08:50

Sample: 20152020

Included observations: 6

\begin{tabular}{crrrr}
\hline \hline \multicolumn{1}{c}{ Variable } & Coefficient & Std. Error & t-Statistic & Prob. \\
\hline \hline C & -5.591208 & 10.48387 & -0.533315 & 0.6881 \\
ROA & 26.88474 & 44.16934 & 0.608674 & 0.6519 \\
ROE & -2.866907 & 3.865628 & -0.741641 & 0.5938 \\
BOPO & -2.197918 & 5.476647 & -0.401326 & 0.7570 \\
& 6.377733 & 12.28825 & 0.519010 & 0.6952 \\
\hline \hline R-squared & 0.630123 & Mean dependent var & 0.043417 \\
Adjusted R-squared & -0.849385 & S.D. dependent var & 0.106349 \\
S.E. of regression & 0.144626 & Akaike info criterion & -1.154427 \\
Sum squared resid & 0.020917 & Schwarz criterion & -1.327961 \\
Log likelihood & 8.463281 & Hannan-Quinn criter. & -1.849097 \\
F-statistic & 0.425900 & Durbin-Watson stat & 3.218565 \\
Prob(F-statistic) & 0.799788 & & & \\
\hline \hline
\end{tabular}

Tabel 13 Indikator Rasio ROA, ROE, NI, BOPO Terhadap DPR

Dependent Variable: DPR

Method: Least Squares

Date: 01/12/21 Time: 08:51

Sample: 20152020

Included observations: 6

\begin{tabular}{lrlrr}
\hline \hline \multicolumn{1}{c}{ Variable } & Coefficient & Std. Error & t-Statistic & Prob. \\
\hline \multicolumn{1}{c}{ CAR } & -0.126800 & 0.149410 & -0.848672 & 0.4439 \\
\multicolumn{1}{c}{ CAR } & 0.507227 & 0.427492 & 1.186517 & 0.3011 \\
\hline \hline R-squared & 0.260331 & Mean dependent var & 0.043417 \\
Adjusted R-squared & 0.075414 & S.D. dependent var & 0.106349 \\
S.E. of regression & 0.102260 & Akaike info criterion & -1.461395 \\
Sum squared resid & 0.041828 & Schwarz criterion & -1.530808 \\
Log likelihood & 6.384184 & Hannan-Quinn criter. & -1.739262 \\
F-statistic & 1.407824 & Durbin-Watson stat & 3.029198 \\
Prob(F-statistic) & 0.301074 & & \\
\hline \hline
\end{tabular}

Tabel 14 Indikator Rasio CAR Terhadap DPR

\section{HASIL DAN PEMBAHASAN}

Pada Tabel 11 Hasil Analisis Kesehatan Bank BTPN Syariah Periode 2015 sampai

Quartal 32020 menghasilkan tingkat kesehatan Bank BTPN Syariah menggunakan metode 
RGEC pada periode 2015 sampai Quartal 3 Tahun 2020 sangat memuaskan. Indikator rasio pada setiap komponen penilaiannya berada pada poin 5, 4, dan 3 .

Pada penilaian risk profile dengan rasio NPF di tahun 2015 sebesar 0,17\% dan mengalami peningkatan di tahun 2016 sebesar 0,20\%. Kemudian, mengalami penurunan di tahun 2017 sebesar 0,05\% dan tahun 2018 sebesar 0,02\%. Namun, tahun 2018 mengalami peningkatan sebesar 0,26\% dan pada quartal 3 tahun 2020 mengalami penurunan sebesar 0,00\%. Bank dikatakan sangat sehat apabila memiliki rasio NPF kurang dari sama dengan 2\%. Serta semakin tinggi rasio NPF suatu bank maka semakin besar tingkat risiko pembiayaan bermasalah yang ditanggung. Maka, dengan persentase rasio NPF bank BTPN Syariah dari tahun 2015 sampai quartal 3 tahun 2020, Bank BTPN Syariah sangat sehat dan bank BTPN Syariah tidak memiliki risiko pembiayaan yang bermasalah. Dengan ini, BTPN Syariah harus mampu mempertahankan dan meningkatkan kinerja keuangan dan operasionalnya supaya tidak terjadi pembiayaan yang bermasalah di periode selanjutnya.

Pada penilaian risk profile dengan rasio FDR ditahun 2015 sebesar 96,54\% dan mengalami penurunan di tahun 2016 dan tahun 2017 masing-masing sebesar 92,75\% dan 92,47\%. Kemudian, pada tahun 2018 mengalami peningkatan sebesar 95,60\% dan tahun 2019 mengalami penurunan sebesar 95,27\%. Dan pada quartal 3 tahun 2020 mengalami peningkatan sebesar $98,48 \%$. Bank dikatakan sangat sehat apabila rasio FDR diantara 50\% sampai dengan $75 \%$. Semakin tinggi rasio FDR, semakin rendah kemampuan likuiditasnya. Serta semakin tinggi rasio FDR menunjukkan penerimaan dana bank semakin besar, sehingga semakin besar dana yang diterima bank, maka semakin tinggi resiko yang ditanggung. Maka, dengan persentase rasio FDR bank BTPN Syariah dari tahun 2015 sampai quartal 3 tahun 2020, Bank BTPN Syariah cukup sehat. Dengan ini, BTPN Syariah memerlukan strategi untuk meningkatkan kemampuan likuiditasnya.

Pada penilaian GCG dengan rasio PDN ditahun 2015 sampai quartal 3 tahun 2020 sebesar 0,00\% menandakan bahwa bank BTPN Syariah tidak melakukan pelanggaran dan mendapatkan predikat sangat sehat. Penilaian GCG ini merupakan penilaian secara kualitatif dengan melihat kepatuhan bank sesuai dengan peraturan yang berlaku. Pada dasarnya rasio PDN ini merupakan peringatan agar bank berhati-hati dalam melakukan transaksi valuta asing dan harus patuh terhadap peraturan Bank Indonesia, serta sebagai pengingat Bank Indonesia untuk menjaga PDN agar rupiah tidak goyah.

Pada penilaian earnings dengan rasio ROA ditahun 2015 sampai tahun 2019 bank BTPN Syariah mengalami peningkatan setiap tahunnya masing-masing sebesar 5,24\%; 
$8,98 \% ; 11,19 \% ; 12,37 \%$; dan 13,58\%. Kemudian, pada quartal 3 tahun 2020 mengalami penurunan sebesar 5,80\%. Bank dikatakan sangat sehat apabila memiliki ROA lebih dari sama dengan 2\%. Dengan besaran ROA bank BTPN Syariah tahun 2015 sampai dengan quartal 3 tahun 2020 dapat dikatakan bahwa bank BTPN Syariah sangat sehat. Semakin besar ROA, maka bank semakin produktif dan efisien. Maka, bank BTPN Syariah harus mampu memanfaatkan asset yang dimiliki untuk produktif dan efisien, sehingga laba yang didapatkan besar dan bank mendapatkan kepercayaan dari nasabah, masyarakat, dan para investor.

Pada penilaian earnings dengan rasio ROE ditahun 2015 sampai tahun 2017 bank BTPN Syariah mengalami peningkatan setiap tahunnya masing-masing sebesar 17,89\%; 31,71\%; dan 36,50\%. Kemudian, pada tahun 2018 mengalami penurunan sebesar 30,82\% dan mengalami peningkatan sebesar 31,20\% di tahun 2019. Pada quartal 3 tahun 2020 mengalami penurunan sebesar 12,79\%. Bank dikatakan sangat sehat apabila ROE lebih besar sama dengan 20\%. Dengan melihat besaran rasio ROE pada bank BTPN Syariah dari tahun 2015 sampai quartal 3 tahun 2020, maka bank BTPN Syariah pada tahun 2015 dan quartal 3 tahun 2020 mendapatkan predikat sehat, sedangkan pada tahun 2016 sampai tahun 2019 mendapatkan predikat sangat sehat.

Pada penilaian earnings dengan rasio NI mengalami pertumbuhan yang fluktuasi dan yang paling tinggi pada tahun 2017 sebesar 35,96\% sedangkan yang paling rendah pada quartal 3 tahun 2020 sebesar 24,13\%. Dengan melihat besaran rasio NI pada tahun 2015 sampai quartal 3 tahun 2020, bank BTPN Syariah termasuk kategori sangat sehat karena NI lebih besar dari $6,5 \%$.

Pada penilaian earnings dengan rasio BOPO dari tahun 2015 sampai tahun 2019 setiap tahunnya mengalami penurunan masing-masing sebesar 85,32\%; 75,14\%; 68,81\%; 62,36\%; dan 58,07\%. Namun, pada quartal 3 tahun 2020 mengalami kenaikan sebesar 77,20\%. Dengan melihat besaran rasio BOPO dari tahun 2015 sampai quartal 3 tahun 2020, maka bank BTPN Syariah masuk kategori sangat sehat karena kurang dari $88 \%$. Semakin tinggi nilai BOPO, semakin tidak efisien operasi bank. Sehingga, semakin besar beban operasional dapat dikatakan operasional bank tersebut buruk. Oleh karena itu, bank BTPN Syariah diharapkan mampu mengelola operasional dengan baik dan efisien.

Pada penilaian capital dengan rasio CAR dari tahun 2015 sampai tahun 2019 setiap tahunnya mengalami kenaikan masing-masing sebesar 19,92\%; 23,80\%; 28,91\%; 40,92\%; dan 44,70\%. Namun, pada quartal 3 tahun 2020 mengalami penurunan sebesar 43,10\%. 
Dengan melihat besaran rasio CAR dari tahun 2015 sampai quartal 3 tahun 2020, maka bank BTPN Syariah masuk kategori sangat sehat karena lebih dari sama dengan 12\%. Semakin besar nilai CAR, maka kemampuan perbankan semakin baik dalam menghadapi risiko kerugian. Oleh karena itu, bank BTPN Syariah memerlukan strategi untuk membesarkan nilai CAR.

Berdasarkan Tabel 15 Hasil Analisis Tingkat Kesehatan Metode RGEC Bank BTPN Syariah Tahun 2015 Sampai Quartal 32020 Secara Umum menunjukkan bahwa tingkat kesehatan bank BTPN Syariah tahun 2015 sampai quartal 32020 secara umum dari semua indikator rasio penilaian berada pada kondisi sangat sehat. Dalam artian bank BTPN Syariah tahun 2015 sampai quartal 32020 memiliki profil risiko yang kecil, sehingga risiko yang dihadapi BTPN Syariah sangat rendah. Selain itu, bank BTPN Syariah memiliki tata usaha yang baik dan patuh terhadap peraturan yang berlaku. Bank BTPN Syariah juga memiliki rentabilitas yang baik, bank mampu mengoptimalkan operasionalnya secara efisien, sehingga menguntungkan segala stakeholders.

\begin{tabular}{|c|c|c|c|c|c|c|}
\hline \multirow{2}{*}{ Rasio } & \multicolumn{7}{|c|}{ Tahun } \\
\cline { 2 - 7 } & $\mathbf{2 0 1 5}$ & $\mathbf{2 0 1 6}$ & $\mathbf{2 0 1 7}$ & $\mathbf{2 0 1 8}$ & $\mathbf{2 0 1 9}$ & $\mathbf{2 0 2 0}$ \\
\hline NPF & 5 & 5 & 5 & 5 & 5 & 5 \\
\hline FDR & 3 & 3 & 3 & 3 & 3 & 3 \\
\hline PDN & 5 & 5 & 5 & 5 & 5 & 5 \\
\hline ROA & 5 & 5 & 5 & 5 & 5 & 5 \\
\hline ROE & 4 & 5 & 5 & 5 & 5 & 4 \\
\hline NI & 5 & 5 & 5 & 5 & 5 & 5 \\
\hline BOPO & 5 & 5 & 5 & 5 & 5 & 5 \\
\hline CAR & 5 & 5 & 5 & 5 & 5 & 5 \\
\hline Total Skor & $\mathbf{3 7}$ & $\mathbf{3 8}$ & $\mathbf{3 8}$ & $\mathbf{3 8}$ & $\mathbf{3 8}$ & $\mathbf{3 7}$ \\
\hline $\begin{array}{c}\text { Nilai } \\
\text { Komposit } \\
\text { (\%) }\end{array}$ & $\mathbf{9 2 , 5}$ & $\mathbf{9 5}$ & $\mathbf{9 5}$ & $\mathbf{9 5}$ & $\mathbf{9 5}$ & $\mathbf{9 2 , 5}$ \\
\hline $\begin{array}{c}\text { Predikat } \\
\text { Sehat }\end{array}$ & $\begin{array}{c}\text { Sangat } \\
\text { Sangat } \\
\text { Sehat }\end{array}$ & $\begin{array}{c}\text { Sangat } \\
\text { Sehat }\end{array}$ & $\begin{array}{c}\text { Sangat } \\
\text { Sehat }\end{array}$ & $\begin{array}{c}\text { Sangat } \\
\text { Sehat }\end{array}$ & $\begin{array}{c}\text { Sangat } \\
\text { Sehat }\end{array}$ \\
\hline
\end{tabular}

Tabel 15 Hasil Analisis Tingkat Kesehatan Metode RGEC Bank BTPN Syariah Tahun 2015 Sampai Quartal 32020 Secara Umum

Bank BTPN Syariah IPO pada tanggal 8 Mei 2018. Sehingga, bank BTPN Syariah wajib membagikan dividen kepada para investor yang memiliki saham bank BTPN Syariah atau BTPS. Kebijakan dividen yang dilakukan oleh bank BTPN Syariah melalui Rapat Umum Pemegang Saham Tahunan (RUPST) secara musyawarah mufakat dan mengambil 
dengan pemutusan suara ini melihat dari history laporan keuangan tahunan dan menyetujui penggunaan laba bersih perseroan tahun buku 2019 sebesar Rp. 1.399.633.812.166,- dan berpedoman pada UU No. 40 Tahun 2007 tentang Perseroan Terbatas dimana menyisihkan untuk cadangan umum perseroan sebesar Rp. 20.000.000.000,- dan sisanya sebagai dividen tunai sebesar Rp. 45,- per lembar saham atau sebesar Rp. 346.554.000.000,- kepada pemegang saham dengan ketentuan akan dikenakan pemotongan pajak dividen menurut tarif sesuai dengan peraturan perpajakan yang berlaku terhadap pemegang saham yang memperoleh pembayaran dividen dan direksi diberi kuasa untuk menetapkan hal-hal yang sesuai dengan pelaksanaan pembayaran dividen. Selain itu, membukukan sisa laba perseroan untuk tahun buku yang berakhir pada 31 Desember 2019 sebesar Rp. 1.033.079.812.166,sebagai laba yang ditahan untuk membiayai kegiatan usaha perseroan. Rasio yang digunakan untuk menentukan kebijakan dividen adalah DPR. DPR membantu manajemen supaya bisa mengeluarkan dividen tanpa merugikan perusahaan dan menyenangkan hati para pemegang saham. Dalam kebijakan dividen ini, bank BTPN Syariah juga melihat tingkat kesehatan banknya. Sehingga, beberapa indikator rasio penilaian tingkat kesehatan bank memiliki pengaruh terhadap rasio DPR kebijakan dividen.

Selanjutnya, untuk mengetahui indikator rasio metode RGEC yang memiliki pengaruh terhadap kebijakan dividen, maka dilakukan uji f dengan tujuan mengetahui pengaruh rasio NPF, FDR, ROA, ROE, NI, BOPO, dan CAR secara bersama-sama terhadap DPR. Selain itu, dilakukan juga uji t dengan maksud untuk mengetahui pengaruh masing-masing dari rasio NPF, FDR, ROA, ROE, NI, BOPO, dan CAR terhadap DPR. Rasio PDN tidak diuji karena pada penilaian GCG lebih menilai melalui kepatuhan bank BTPN Syariah terhadap peraturan dan adakah pelanggaran yang perna dilakukan. Uji f dilakukan dengan membandingkan f-statistic dengan f-tabel, sedangkan uji $t$ dilakukan dengan membandingkan t-statistic dengan t-tabel. Adapun, probabilitas yang dipakai adalah 0,50 karena dua arah.

Berdasarkan Tabel 12 Indikator Rasio NPF dan FDR Terhadap DPR dapat dilihat bahwa hasil f-statistic sebesar 1,36 dan f-tabel yang diperoleh adalah 0,83. Sehingga, fstatistic > f-tabel atau 1,36 >0,83, maka rasio NPF dan FDR pada penilaian risk profile memiliki pengaruh yang signifikan terhadap DPR pada kebijakan dividen. Adapun, hasil tstatistic yang didapatkan rasio NPF sebesar 1,65, sedangkan t-statistic yang diperoleh rasio FDR sebesar 0,53 dan t-tabel yang didapatkan adalah 0,74. Maka, yang memiliki pengaruh besar terhadap DPR pada kebijakan dividen untuk penilaian risk profile adalah rasio NPF 
karena t-statistic pada NPF $>\mathrm{t}$-tabel atau 1,65 >0,74. Melalui rasio NPF dan FDR pada penilaian risk profile memiliki pengaruh yang signifikan terhadap rasio DPR pada kebijakan dividen, tetapi rasio yang memiliki pengaruh besar terhadap kebijakan dividen hanya rasio NPF dari indikator penilaian risk profile. Bank BTPN Syariah diharuskan memiliki kinerja yang lebih bagus untuk meningkatkan aktiva produktif supaya tidak terjadi pembiayaan yang bermasalah, sehingga bank BTPN Syariah dapat membagikan dividen yang diharapkan oleh para investor atau pemegang saham dan tidak merugikan operasional bank BTPN Syariah.

Berdasarkan Tabel 13 Indikator Rasio ROA, ROE, NI, BOPO Terhadap DPR dapat dilihat bahwa hasil $\mathrm{f}$-statistic sebesar 0,80 dan f-tabel didapatkan 1,21. Sehingga, f-statistic $<$ f-tabel maka rasio ROA, ROE, NI, dan BOPO pada penilaian earnings tidak memiliki pengaruh yang signifikan terhadap DPR pada kebijakan dividen. Adapun, hasil t-statistic yang didapatkan rasio ROA sebesar 0,61; rasio ROE sebesar -0,74; rasio NI sebesar -0,40; sedangkan t-statistic yang diperoleh rasio BOPO sebesar 0,52 dan t-tabel yang didapatkan adalah 1,00. Maka, keempat rasio penilaian earnings ini masing-masingnya tidak memiliki pengaruh yang besar terhadap DPR pada kebijakan dividen. Meskipun, indikator rasio penilaian earnings tidak memiliki pengaruh yang signifikan terhadap DPR pada kebijakan dividen dan masing-masing dari rasio penilaian earnings tidak memiliki pengaruh yang besar terhadap DPR pada kebijakan dividen, bank BTPN Syariah tetap harus mengoptimalkan asset dan equitynya supaya beban atau biaya operasional bisa diminimalisirkan, sehingga bank berada dalam kondisi aman dan masyarakat serta para pemegang saham atau investor semakin percaya dan tertarik dengan bank BTPN Syariah.

Berdasarkan Tabel 14 Indikator Rasio CAR Terhadap DPR dapat dilihat bahwa hasil f-statistic sebesar 1,41 dan f-tabel yang diperoleh adalah 0,53. Sehingga, f-statistic > f-tabel atau 1,41 > 0,53, maka rasio CAR pada penilaian capital memiliki pengaruh yang signifikan terhadap DPR pada kebijakan dividen. Adapun, hasil t-statistic yang didapatkan rasio CAR sebesar 1,19 dan t-tabel yang didapatkan adalah 0,73. Maka, rasio CAR untuk penilaian capital memiliki pengaruh besar terhadap DPR pada kebijakan dividen karena t-statistic pada CAR > t-tabel atau 1,19>0,73. Dalam hal ini, bank BTPN Syariah harus bisa mengoperasionalkan jumlah modal yang dimiliki dengan sebaik-baiknya supaya tidak terjadi kerugian yang besar sehingga bank dapat membagikan dividen yang sesuai.

Melihat Tabel 15 Hasil Analisis Tingkat Kesehatan Metode RGEC Bank BTPN Syariah Tahun 2015 Sampai Quartal 32020 Secara Umum, bank BTPN Syariah memiliki tingkat kesehatan bank yang sangat sehat dan hal ini memiliki pengaruh positif untuk 
membagikan dividen diperkuat dengan besaran rasio NPF dan CAR yang masing-masing memiliki pengaruh besar terhadap kebijakan dividen. Sehingga, bank BTPN Syariah memerlukan strategi khusus untuk selalu meningkatkan kinerja operasional dan keuangannya supaya bank BTPN Syariah tidak mengecewakan para stakeholders dan mampu mengeluarkan dividen yang diharapkan tanpa merugikan pihak perusahaan bank BTPN Syariah.

\section{KESIMPULAN}

Berdasarkan hasil penelitian analisis tingkat kesehatan bank BTPN Syariah tahun 2015 sampai quartal 32020 menggunakan metode RGEC menunjukkan bahwa bank BTPN Syariah sangat sehat, meskipun beberapa rasionya terdapat perkembangan yang fluktuaktif, namun di masa pandemic covid-19 ini bank BTPN Syariah masih stabil untuk meningkatkan kinerja keuangan dan operasionalnya. Sehingga, kondisi kesehatan bank BTPN Syariah tetap pada peringkat 1 yaitu sangat sehat. Selain itu, dengan faktor tingkat kesehatan bank BTPN Syariah yang sangat sehat menghasilkan kemampuan bank untuk membagikan dividen dengan patokan rasio DPR yang menguntungkan seluruh stakeholders dan tidak merugikan perusahaan bank BTPN Syariah. Hal ini diperkuat dengan rasio NPF pada penilaian risk profile yang memiliki pengaruh besar terhadap DPR pada kebijakan dividen sebesar 1,65 dan rasio CAR pada penilaian capital yang memiliki pengaruh besar terhadap DPR pada kebijakan dividen sebesar 1,41.

\section{KETERBATASAN DAN SARAN}

Keterbatasan dalam penelitian ini adalah mendapatkan informasi secara langsung dari pihak perbankan dikarenakan kondisi pandemic. Adapun saran yang dapat diberikan oleh penulis kepada bank BTPN Syariah agar bisa menjaga dan mempertahankan tingkat kesehatan banknya dalam predikat sangat sehat serta bank mampu menentukan kebijakan dividen dan dapat membagikan dividennya adalah bank BTPN Syariah harus mengoptimalkan asset dan modal, sekaligus meminimalisir biaya operasional yang dikeluarkan, sehingga bank mendapatkan laba yang besar, tidak terjadi kerugian, dan tidak ada kredit pembiayaan yang bermasalah. Salah satu cara yang dapat dilakukan adalah bank BTPN Syariah menganalisis minat atau kemauan para nasabah seperti apa supaya produk dan jasa bank BTPN Syariah semakin terdepan dan bank BTPN Syariah bisa melakukan inovasi dari segala aspek. Selain itu, bank BTPN Syariah juga harus memperkuat good government corporatenya. Sedangkan, saran yang dapat diberikan oleh penulis kepada penelitian selanjutnya adalah menambah indikator rasio keuangan yang mempertajam analisis tingkat kesehatan bank dan 
menambah variabel lain untuk memperkuat pengaruh analisis tingkat kesehatan bank terhadap kebijakan dividen.

\section{DAFTAR PUSTAKA}

Agni, M., \& Sugiri, S. (2015). PENGARUH TINGKAT KESEHATAN BANK TERHADAP PEMBAGIAN DIVIDEN (Studi Empiris pada Bank Umum yang Terdaftar di Bursa Efek Indonesia Periode 2009-2013) [Skripsi]. Universitas Gadjah Mada.

Apriliani, A., \& Natalylova, K. (2017). FAKTOR-FAKTOR YANG MEMPENGARUHI KEBIJAKAN DIVIDEN PADA PERUSAHAAN MANUFAKTUR DI BURSA EFEK INDONESIA. Jurnal Bisnis dan Akuntansi, 19(1), 49-57.

Ardyanfitri, H., Surya Pratikto, M. I., \& Khusnul Faizah, E. A. (2019). ANALISIS KESEHATAN BANK DAN POTENSI FINANCIAL DISTRESS MENGGUNAKAN METODE RGEC PADA BANK BTPN SYARIAH TAHUN 2014-2018. MEBIS Jurnal Manajemen dan Bisnis, 4, 59-69.

Company Data \& User Guide. (2020, Desember). [Ksei.co.id]. ksei.co.id/data/graph.

Fortrania, L. M., \& Oktaviana, U. K. (2015). ANALISIS TINGKAT KESEHATAN BANK UMUM SYARIAH DAN UNIT USAHA SYARIAH DENGAN METODE CAMELS DAN RGEC. El-Dinar, 3, 118-126.

Gita Maheswari, I. G. A., \& Suryanawa, I. K. (2016). PENGARUH TINGKAT KESEHATAN BANK DAN UKURAN BANK TERHADAP NILAI PERUSAHAAN. E-Jurnal Akuntansi Universitas Udayana, 16.2, 1319-1346.

PENGUMUMAN RINGKASAN RISALAH RAPAT UMUM PEMEGANG SAHAM TAHUNAN PT BANK TABUNGAN PENSIUNAN NASIONAL SYARIAH TBK. (2020, April 20). Bisnis Indonesia, 11.

Prastyananta, F., Saifi, M., \& Wi Endang, M. G. (2016). ANALISIS PENGGUNAAN METODE RGEC (RISK PROFILE, GOOD CORPORATE GOVERNANCE, EARNING, CAPITAL) UNTUK MENGETAHUI TINGKAT KESEHATAN BANK (Studi Pada Bank Umum Yang Terdaftar Di BEI Periode 2012-2014). Jurnal Administrasi Bisnis (JAB), 35 .

Rosifah, S. N. (2021, Januari 2). Dampak Pandemi Terhadap Perekonomian [Ideas.or.id]. ideas.or.id/data-statistik/.

Santoso, T. B., \& Nuritomo. (2014). Bank Dan Lembaga Keuangan Lain. Salemba Empat. 


\section{P ISSN 2622-7177 \\ [ACCOUNTING GLOBAL JOURNAL] E ISSN 2623-1778}

Sugiyono. (2018). Metode Penelitian Kuantitatif, Kualitatif, dan Kombinasi (Mixed Methods). Alfabeta.

Sumadi. (2020). MENAKAR DAMPAK FENOMENA PANDEMI COVID-19 TERHADAP PERBANKAN SYARIAH. Jurnal Hukum Ekonomi Syariah, 3, 145162. 